\title{
Analisis Pentingnya Implementasi Penyelesaian Sengketa Online di Indonesia
}

\author{
Vizta Dana Iswara, Nur Hadiyati \\ Sarjana Hukum, Ilmu Hukum, Universitas Internasional Batam, Kepulauan Riau, Indonesia \\ Correspondence email: Vizta.iswara@gmail.com ; email: hadiyati@uib.ac.id
}

\begin{abstract}
Online Dispute Resolution (ODR) is a legal innovation that utilizes technological advances in alternative dispute resolution methods in which through the ODR, the disputing parties do not need to meet directly to resolve their disputes. The method used by the writer in this scientific journal is the normative research method. The researcher uses secondary data in the form of document studies, journals, literature and research journals and other sources that can be used as the material in this scientific article. ODR is expected to facilitate the dispute resolution process arising from cross-border trade transactions, where conventional judicial mechanisms may not offer adequate solutions or legal assistance to resolve cross-border e-Commerce disputes. Currently, there are 4 types of dispute resolution systems using ODR, namely e-Settlement, e-Arbitration, e-Resolution and e-Mediation. However, several things must be considered if Indonesia wants to implement this ODR method, namely Indonesia needs to pay attention to and consider technological barriers, access and affordability as well as obstacles to system security and confidentiality of personal data.
\end{abstract}

Keywords: Online, Dispute, Resolution

\begin{abstract}
Abstak. Online Dispute Resolution (ODR) merupakan sebuah inovasi hukum yang memanfaatkan kemajuan teknologi dalam metode penyelesaian sengketa alternatif dimana melalui jalur ODR pihak yang bersengketa tidak perlu bertemu secara langsung untuk menyelesaikan sengketa mereka. Metode yang yang digunakan penulis pada jurnal ilmiah ini adalah metode penelitian normatif. Peneliti menggunakan data sekunder berupa studi dokumen, literatur serta jurnal penelitian dan sumber-sumber lain yang dapat digunakan sebagai materi dalam artikel ilmiah ini. ODR diharapkan dapat mempermudah proses penyelesaian sengketa yang timbul dari transaksi perdagangan lintas batas, dimana mekanisme peradilan konvensional kemungkinan tidak menawarkan solusi atau bantuan hukum yang memadai untuk mengatasi sengketa e-Commerce lintas batas. Pada saat ini terdapat 4 macam sistem penyelesaian sengketa menggunakan ODR yaitu e-Settlement, e-Arbitration, e-Resolution dan e-Mediation. Namun, beberapa hal yang harus diperhatikan jika Indonesia ingin mengimplementasikan metode ODR ini yaitu Indonesia perlu untuk memperhatikan dan mempertimbangkan perihal hambatan teknologi, akses dan keterjangkauan serta kendala terhadap keamanan sistem dan kerahasiaan data pribadi.
\end{abstract}

Kata kunci: Online, Sengketa bisnis, Penyelesaian

\section{PENDAHULUAN}

Hadirnya interaksi yang timbul antar manusia tentunya tidak lepas akan hadirnya konflik serta perselisihan akibat perbedaan baik itu berupa kepentingan maupun pendapat. Karena ini disebabkan oleh manusia yang mana merupakan makhluk sosial yang saling berketergantungan antar satu dengan yang lain. Sehingga, hukum memiliki peran yang signifikan dalam penyelesaian perkara atau konflik yang timbul akibat perselihisan tersebut. Inilah yang menjadikan salah satu fungsi utama hukum yaitu sebagai sarana untuk penyelesaian konflik serta sebagai sarana guna untuk memperlancar interaksi sosial ${ }^{1}$.

Namun pada era digitalisasi ini, diketahui bahwa internet telah mengambil peran yang sangat penting dalam kehidupan teruntuk banyak orang. Perkembangan globalisasi yang signifikan khususnya pada Teknologi Informasi dan Komunikasi (TIK) baik di negara maju maupun berkembang menciptakan perubahan-perubahan yang signifikan tidak hanya pada perekonomian secara global namun juga pada aspek politik, budaya, teknologi, lingkungan serta sosial dan budaya. Ini menyebabkan jarak yang kian menyusut sementara waktu kian dipercepat. Tanpa kita sadari bahwa saat ini kita telah tinggal di dunia yang lebih kecil dan cepat dibandingkan dengan sedekade yang lalu yaitu dunia penuh akan oportunitas yang baru serta ekspektasi yang baru namun juga dunia yang penuh dengan tantangan yang baru ${ }^{2}$.

Di dunia yang penuh dengan oportunitas serta ekspektasi yang baru tentunya mengakibatkan timbulnya permasalahan atau perselisihan yang kian banyak serta beragam. Contohnya dapat dilihat dari sudut pandang pesatnya perkembangan globalisasi dapat dilihat dari sektor perdagangan yang mana akses perdagangan itu sendiri pada saat ini menjadi semakin tanpa batas (borderless). Salah satu penerapaan perdagangan yg tanpa batas adalah perdagangan

1 Sitompul, M. G., Syaifuddin, M., \& Yahanan, A. (2016). Online Dispute Resolution (ODR): Prospek Penyelesaian Sengketa E-Commerce di Indonesia. Jurnal Renaissance, 1(2), 75-93.

${ }^{2}$ Aziz, M., \& Hidayah, M. (2020). Perlunya Pengaturan Khusus Online Dispute Resolution (ODR) Di Indonesia Untuk Fasilitasi Penyelesaian Sengketa E-Commerce. Jurnal Rechts Vinding: Media Pembinaan Hukum Nasional, 9(2), 275-278. doi: 10.33331/rechtsvinding.v9i2.449 
internasional, definisi perdagangan internasional itu sendiri sebagaimana yang disebutkan oleh DA Iswandari merupakan perdagangan atau sebuah proses tukar menukar yang terjadi atas kesepakatan bersama dan itu terdiri dari 2 negara atau lebih ${ }^{3}$. Adapun aktivitas perdagangan internasional yaitu transaksi seperti jual-beli, tawar-menawar sampai dengan dengan ekspor dan impor pada saat ini dapat dilaksanakan antar masyarakat internasional.

Orang-orang dan bisnis yang tidak akan pernah berurusan satu sama lain pada saat ini melakukan bisnis bersama-sama dan mengadakan perjanjian atau membuat kontrak karena adanya internet. Pelanggan yang secara tradisionalnya terbatas hanya kepada pasar domestik, kini telah dapat berbelanja di luar negeri. Pebisnis dengan skala kecil dan menengah kini telah memasuki pasar internasional yang mana ini dahulunya di peruntukkan untuk bisnis dengan skala besar. Ini membuat aktivitas perdagangan internasional menjadi semakin berjalan dan berkembang dengan sangat pesat ${ }^{4}$.

Belum lagi dengan munculnya e-Commerce yang mempermudah transaksi baik dalam negeri maupun luar negeri yang mana menyebabkan jarak interaksi perdagangan semakin kecil. Ini dikarenakan e-Commerce yang menawarkan konsumen online banyak pilihan produk dan bisnis dengan basis pelanggan potensial yang sangat besar sehingga menyebabkan Electronic commerce (e-Commerce) menjadi pasar terbesar dan paling cepat berkembang di dunia. $^{5}$

Bersamaan dengan peningkatan tajam selama dua dekade terakhir sehubungan dengan transaksi komersial yang dilakukan melalui Internet seperti perdagangan elektronik Business to Business (B2B), Business to Customer (B2C), dan Customer to Customer (C2C) telah menghasilkan diskusi ekstensif mengenai penggunaan sistem - baik yudisial atau ekstrayudisial - untuk menyelesaikan masalah domestik dan internasional yang mana sengketa lintas batas yang secara pasti akan timbul sebagai bagian dari pengelolaan jenis transaksi komersial ini ${ }^{6}$. Bersamaan dengan peningkatan perdagangan internasional dan juga praktik e-Commerce maka menyebabkan munculnya sengketa antar pihak yang terlibat pada aktivitas perdagangan internasional tersebut.

Apabila terjadi sengketa antar pelaku aktivitas perdagangan internasional maka upaya yang dapat dilakukan untuk menyelesaikan sengketa tersebut adalah melalui upaya litigasi atau non-litigasi. Upaya penyelesaian sengketa secara litigasi adalah merupakan upaya penyelesaian sengketa melalui Lembaga peradilan dan prosesnya dilaksanakan sesuai dengan prosedur pengadilan. Sementara itu, upaya penyelesaian sengketa via non-litigasi adalah upaya yang dilakukan antar pihak bersengkata tanpa mencampur tangankan lembaga perdailan atau dengan kata lain yaitu penyelesaian sengketa diluar pengadilan ${ }^{7}$.

Namun tidak dapat dipungkiri bahwa pada saat ini, dunia telah berada pada era Revolusi Industri 4.0 yang mana semua proses itu dilalui via komputerisasi serta digitalisasi dan sistem hukum itu sendiri tidak dapat terhindari dari dampak Revolusi Industri 4.0. Contohnya dapat dilihat di lingkungan peradilan yang mana kegiatan praktik hukum yang dulunya dilakukan secara konvensional namun sekarang telah mengenal yang namanya proses digitalisasi ${ }^{8}$.

Disamping itu juga pada saat ini terdapat metode baru penyelesaian sengketa non-litigasi yang muncul karena diakibatkan oleh kemajuan teknologi informasi yang kemudian dikenal dengan Online Dispute Resolution atau disingkat sebagai ODR. Metode yang digunakan Online Dispute Resolution guna untuk menyelesaikan suatu sengketa sebenarnya hampir sama dengan metode ADR atau arbitrase, namun letak perbedaannya hanyalah upaya pelaksanaannya saja dimana ODR itu dilakukan secara online $e^{9}$.

Karena, tidak dapat dipungkiri bahwa seiring dengan meningkatnya pertumbuhan penduduk disertai dengan pesatnya perkembangan teknologi mengakibatkan meningkatnya pertumbuhan intensitas transaksi bisnis secara signifikan. Sehingga intensitas ini, memicu jumlah sengketa bisnis baik dalam wilayah domestic maupun internasional. Maka, dengan adanya kondisi ini, maka sangat dibutuhkan suatu sistem yang sederhana namun tepat, cepat dan tentunya efektif serta efisien. Perlu juga untuk digarisbawahi bahwa metode penyelesaian tersebut harus ringkas namun biaya yang harus dikeluarkan juga ringan. Dengan demikian, Alternative Dispute Resolution merupakan jawaban dari permasalahan sebagaimana yang telah disebutkan diatas karena ADR memiliki kriteria tersebut yaitu sederhana dan ringkas serta biaya yang ringan. Jadi, bukan hanya lewat jalur litigasi saja suatu sengketa

\footnotetext{
Iswandari, D. (2018). Teori Perdagangan Internasional. Retrieved 14 December 2020, from http://eprints.ums.ac.id/59653/7/BAB\%20II.pdf

4 Chandra, A. (2014). Penyelesaian Sengketa Transaksi Elektronik Melalui Online Dispute Resolution (ODR) Kaitan dengan UU Informasi dan Transaksi Elektronik No. 11 Tahun 2008. Jurnal Ilmu Komputer, 10(2).

${ }^{5}$ Faiz Aziz, M., \& Arif Hidayah, M. (2020). Perlunya Pengaturan Khusus Online Dispute Resolution (ODR) Di Indonesia

Untuk Fasilitasi Penyelesaian Sengketa E-Commerce. Jakarta Selatan: Sekolah Tinggi Hukum Indonesia Jentera.

${ }^{6}$ Tsurel, D., Doron, M., Nus, A., Dagan, A., Guy, I., \& Shahaf, D. (2020). E-Commerce Dispute Resolution Prediction (pp. 1465-1474). Virtual Event, Ireland: Association for Computing Machinery.

${ }^{7}$ Faiz Aziz, M., \& Arif Hidayah, M. (2020). Loc.Cit.

${ }^{8}$ Lumbanraja, A. D. (2020). Perkembangan Regulasi Dan Pelaksanaan Persidangan Online Di Indonesia Dan Amerika Serikat Selama Pandemi Covid-19. CREPIDO, 2(1), 46-58. https://doi.org/10.14710/crepido.2.1.46-58

${ }^{9}$ Sugiarto, S. (2019). Online Dispute Resolution (Odr) Sebagai Alternatif Penyelesaian Sengketa Di Era Modernisasi
} 
itu dapat diselesaikan. Namun, juga ada upaya lain melalui non litigasi yaitu Alternative Dispute Resolution atau diartikan sebagai Penyelesaian Sengketa Alternatif ${ }^{10}$.

Disamping itu ADR juga menawarkan upaya penyelesaian secara online atau dikenal dengan Online Dispute Resolution (ODR). Sebagaimana yang telah disebutkan bahwa penyelesaian sengketa melalui jalur ODR itu dilakukan secara online tanpa mengharuskan kedua belah pihak yang bersengketa yang berada di wilayah lintas batas untuk bertemu secara langsung atau bertatap muka. Dengan demikian, Online Dispute Resolution diharapkan dapat membantu serta mengatasi dalam menangani situasi yang timbul dari transaksi perdagangan lintas batas, yang mana mekanisme peradilan yang tradisional kemungkinan tidak menawarkan solusi atau bantuan hukum yang memadai untuk mengatasi sengketa e-Commerce lintas batas (cross-border) ${ }^{11}$.

Di Indonesia sendiri sebagaimana diketahui merupakan salah satu negara yang memiliki populasi penduduk paling padat di dunia dan tentunya ini menjadi salah satu patokan bahwa Indonesia memiliki pengaruh yang signifikan pada perekonomian terutama di mata internasional. Ini dibuktikan dengan adanya pertumbuhan volume transaksi $e$ Commerce pada September 2020 mencapai sebanyak 150,16 juta transaksi, meningkat 79,38 persen secara tahunan (year-on-year/yoy), dari 83,71 juta transaksi pada September $2019^{12}$. Sementara secara bulanan, volume transaksi $e$ Commerce masih mengalami pertumbuhan 1,7 persen month-to-month $(\mathrm{mtm})$ dibandingkan dengan Agustus 2020 yang tercatat mencapai 147,66 juta transaksi. Ditambah dengan letak negara Indonesia yang strategis secara geografis tentunya meningkatkan intensitas transaksi bisnis baik secara nasional maupun internasional ${ }^{13}$.

Sehingga seiring dengan meningkatnya intensitas interaksi bisnis di Indonesia dikhawatirkan bahwa sengketa atau perselisihan bisnis di Indonesia juga akan kian meningkat. Karena seperti yang telah disebutkan diatas bahwa apabila tingkat interaksi bisnis semakin meningkat maka semakin meningkat pula sengketa bisnis yang timbul di negara tersebut ${ }^{14}$.

Berdasarkan latar belakang sebagaimana yang telah di uraikan di atas maka diperlukan kajian lebih lanjut mengenai pentingnya penyelesaian sengketa online di Indonesia serta apa saja manfaat serta tantangan yang akan dihadapi apabila penyelesaian sengketa online benar di berlakukan di Indonesia.

\section{METODE}

Metode yang digunakan penulis pada artikel ilmiah ini adalah metode penelitian normative yang mana pada penelitian ini peneliti menggunakan prosedur penelitian ilmiah yang dilihat dari aspek normative. Normative Law Research atau diartikan menjadi penelitian hukum normative digunakan dengan memanfaatkan studi kasus normative berupa produk prilaku hukum seperti mengkaji hukum positif yang terdapat didalam Undang-Undang. Adapun pokok kajiannya adalah dengan memanfaatkan data sekunder atau bahan Pustaka yang mana dalam konteks ini berupa norma maupun kaidah hukum positif atau yang berlaku di dalam lingkungan masyarakan dan menjadi patokan perilaku setiap orang. Adapun focus dari penelitian hukum normative yaitu undang-undang hukum positif, doktrin hukum, asas-asas hukum, penemuan hukum, perbandingan hukum serta sejarah hukum ${ }^{15}$.

Melalui proses penelitian ini peneliti bertujuan untuk menemukan suatu aturan, prinsip maupun doktrin hukum guna untuk permasalahn hukum yang dihadapi.

Pada penelitian hukum normative ini, penerliti memanfaatkann jenis data sekunder. Adapun bahan hukum primer yang di gunakan adalah berupa hukum perUndang-Undangan. Sementara bahan hukum sekunder sendiri merupakan studi dokumen atau kepustakaan yang mana data tersebug didapatkan dengan cara mengumpulkan, memeriksa dan menelusuri dokumen dan atau kepustakaan yang bisa memberikan informasi atau keterangan terkait penelitian hukum tersebut. Dalam konteks penelitian hukum ini, data sekunder yang dimaksud adalah bahan hukum yang mempunyai kekuatan hukum tetap yang bersifat mengikat seperti peraturan perundang-undangan. Kemudian peneliti juga melakukan pengumpulan bahan dan materi yang terdapat pada buku referensi ${ }^{16}$.

Guna untuk menjawab isu hukum pada permasalahn ini makan dilakukan pengumpulan bahan hukum dengan cara memahami secara lebih mendalam aturan hukum yang berlaku kemudian dilanjutkan dengan mengidentifikasi

${ }^{10}$ Sitompul, M. G., Syaifuddin, M., \& Yahanan, A. (2016). Loc. Cit.

11 UNCITRAL Technical Notes on Online Dispute Resolution. (2017). Retrieved 9 March 2021, from https://uncitral.un.org/sites/uncitral.un.org/files/media-documents/uncitral/en/v1700382_english_technical_notes_on_odr.pdf

12 Elena, M. (2020). Transaksi E-Commerce Meningkat 79,38 Persen di Tengah Resesi Ekonomi | Ekonomi - Bisnis.com. Retrieved 5 May 2021, from https:/ekonomi.bisnis.com/read/20201109/9/1315333/transaksi-e-commerce-meningkat-7938persen-di-tengah-resesi-ekonomi

${ }^{13}$ Chandra, A. (2014). Loc. Cit.

14 Sutiyoso, B. (2008). Penyelesaian Sengketa Bisnis Melalui Online Dispute Resolution dan Pemberlakuannya di Indonesia. Mimbar Hukum-Fakultas Hukum Universitas Gadjah Mada, 20(2), 229-250.

$15 \quad$ Metode Penelitian. (2020).

http://repository.uib.ac.id/1151/6/S_1451007_chapter3.pdf

16 Lam, W., 2018. Metode Penelitian. [online] Repository.uib.ac.id. Available at:

$<$ http://repository.uib.ac.id/1146/6/S_1451010_chapter3.pdf $>$ [Accessed 19 December 2020]. 
bahan Pustaka semisal jurnal hukum, laporan hasil penelitian dan sumber hukum lainnya yang relavan dengan permasalah hukum pada artikel ilmiah ini yaitu penyelesaian permasalahan sengketa perdangan bisnis antar batas dengan menggunakan jalur Online Dispute Resolution.

Metode analisis data yang peneliti terapkan pada penelitian hukum ini yaitu metode analisis kualitatif data yang mana melalui metode ini penulis dapat memperoleh jawabah berdasarkan hasil riset serta pencarian secara normative serta hal-hal yang terkait lainnya. Karena sebagaimana diketahui bahwasanya metoder analisis data kualitatif adalah metode analisis yang memperoleh data dengan cara mengelompokkan serta menseleksi data hasil temuan dari hasil penelitian yang kemudian hasil kebenarannya ditata secara sistematis. Kemudian, data tersebut dihubungkan dengan teori-teori yang didapat dari hasil studi kepustakaan dan dikaji dengan metode berfikir guna untuk mendapatkan kesimpulan maupun jawab yang ditujukan untuk menjawab permasalahan yang terdapat pada penelitian ini.

\section{HASIL DAN PEMBAHASAN}

\section{Teori Online Dispute Resolution}

Saat ini kemajuan teknologi tidak hanya berefek kepada sektor ekonomi saja, tetapi juga kepada sector hukum. Pada sektor hukum sendiri, telah ditemukannya inovasi-inovasi hukum baru yang mana bertujuan untuk mengatasi permasalahan sengketa e-Commerce tersebut. Jika sebelum-sebelumnya sengketa perdagangan diatasi melalui proses litigasi (persidangan) maupun non-litigasi secara langsung, manual, dan tradisional, namun pada saat ini telah ditemukan sebuah inovasi hukum baru yang mana sengketa yang disengketakan dapat diselesaikan secara online. Adapun penyelesaian sengketa yang dilakukan melalui internet tersebut dikenal dengan sebutan Online Dispute Resolution atau disingkat sebagai ODR ${ }^{17}$.

Sementara itu, tujuan dari hadirnya ODR yakni guna untuk meningkatkan kepercayaan masyarakat terhadap kegiatan perdagangan secara daring melalui media elektronik (e-Commerce) dengan menyediakan penyelesaian sengketa yang cepat dan kepastian hukum lintas geografi, bahasa dan yurisdiksi hukum yang berbeda. ECommerce sendiri merupakan sebuah bisnis model yang mengizinkan perusahaan-perusahaan maupun individu untuk melakukan transaksi perdagangan bisnis melalui internet atau secara online. Kegiatan transaksi perdagangan dengan menggunakan e-Commerce dapat dilakukan melalui computer, tablet maupun ponsel pintar selama gadget tersebut tersambung ke internet.

Sejak pandemi Covid-19, diketahui bahwa telah terjadinya peningkatan yang signifikan dalam pertumbuhan volume transaksi e-Commerce pada September 2020 dimana mencapai sebanyak 150,16 juta transaksi atau dengan kata lain telah terjadi peningkatan sebanyak 79,38 persen secara tahunan (year-on-yearlyoy), dari 83,71 juta transaksi pada September 2019. Hal ini menjadikan e-Commerce sebagai salah satu inovasi yang disruptif karena e-Commerce telah membuat sebuah pasar dan juga layanan networking baru yang tentunya mengganggu pasar dan layanan networking yang sudah ada ${ }^{18}$. Sehingga inovasi e-Commerce ini telah menimbulkan ragam sengketa yang baru yang mana kemudian disebut sebagai e-Commerce dispute. Karena semakin meningkatnya kegiatan $e$ Commerce ini makan peluang akan munculnya suatu sengketa yang disebabkan oleh e-Commerce akan semakin besar. Salah satu contoh dari sebagian banyak sengketa yang timbul adalah akibat dari perbuatan hukum dalam $e$ Contract yang disebabkan oleh perjanjian atau kontrak dagang dilakukan dengan memanfaatkan media elektronik. E-Contract juga merupakan salah satu inovasi hukum yang mana kontrak yang pada umumnya dilakukan secara manual dan tradisional sekarang dapat dilakukan secara online ${ }^{19}$.

Sebagaimana yang disebutkan oleh Van Den Heuvel pada saat ini terdapat 4 macam sistem penyelesaian sengketa yang menggunakan mekanisme ODR yang mana akan dijelaskan sebagai berikut ${ }^{20}$.

a. Online settlement.

Yang dimaksud pada Online Settlement ini adalah lebih kepada penyelesaian sengketa mengenai klaim finansial secara online. Online settlement diartikan sebagai penyelesaian daring. Penyelesaian sengketa terkait masalah finansial ini berkembang di Amerika Serikat. Walaupun penyelesaian ODR dengan metode ini tidak selalu berkaitan dengan e-Disputes atau permasalahan yang timbul karena aktifitas yang terjadi pada dunia internet, namun penyelesaian saring ini merupakan salah satu penyelesaian yang paling berkembang sampai dengan saat ini. Cybersettle merupakan website pertama yang menyediakan pelayanan untuk penyelesaian sengketa sehubungan dengan finansial klaim sebelum kemudian diikuti oleh clicknsettle.

\footnotetext{
${ }^{17}$ Kaufmann-Kohler, G., \& Schultz, T. (2004). Online dispute resolution (pp. 5-9). The Hague: Kluwer law international.

${ }^{18}$ Elena, M. (2020). Loc.Cit.

${ }^{19}$ Gerarita Sitompul, M., Syaifuddin, M., \& Yahanan, A. (2016). Online Dispute Resolution (Odr): Prospek Penyelesaian
} Sengketa E-Commerce Di Indonesia. Palembang. Retrieved from https://media.neliti.com/media/publications/255784-onlinedispute-resolution-odr-prospek-pe-52db2b41.pdf

${ }^{20}$ Van Den Heuvel, E. (2020). Online Dispute Resolution As A Solution To Cross-Border E-Disputes. Retrieved 17 December 2020, from http://www.oecd.org/digital/consumer/1878940.pdf 
b. Online arbitration.

Online arbitration atau dalam Bahasa Indonesia diartikan sebagai arbitrase daring yang mana upaya penyelesaian sengketa ini menggunakan fitur teknologi untuk menyelesaikan sengketa yang disengketakan dengan bantuan pihak ketiga yaitu arbiter. Pada metode penyelesaian sengketa ini, para pihak yang bersengketa dapat menyelesaikan sengketa mereka yang timbul karena hubungan kontrak online mereka. Arbitrase online ini pada umumnya digunakan untuk penyelesaian sengketa perdagangan elektronik lintas batas antar bisnis-ke-bisnis (B2B) dan sebagian lainnya digunakan untuk penyelesaian sengketa komersial lintas batas tradisional ${ }^{21}$.

c. Online resolution.

Online resolution atau diartikan sebagai resolusi daring ini diaplikasikan untuk pengajuan pengaduan konsumen yang mana mekanisme ODR ini tidak secara penuh diterapkan secara online. Yang dimaksud dengan penerapan yang tidak diaplikasikan secara penuh dalam konteks ini yaitu pengaduan yang diajukan oleh konsumen dapat dilakukan secara online, namun perkara tersebut belum dapat teratasi secara penuh melalui internet. Sementara itu, BBBOnline merupakan Lembaga yang menyediakan jasa penyelesaian sengketa sehubungan dengan keluhan konsumen yang berlokasi di Amerika Serikat.

Jadi pertama-tama, BBBOnline akan menerima keluhan dari konsumen. Kemudian BBBOnline akan mencoba melakukan konsiliasi secara sederhana yaitu dengang pendekatan kepada orang yang tepat didalam sebuah perusahaan. Pada umumnya, dengan melalui metode ini, masalah akan cepat terselesaikan. Namun, apabila konsiliasi tersebut gagal, maka proses mediasi yang telah disederhanakan akan direalisasikan melalui email dan telepon. Jadi, walaupun penerapannya tidak sepenuhnya dilakukan secara online, namun setidaknya Langkah pertama telah dilaksanakan.

d. Online mediation.

Secara harfiah, mediasi dianggap sebagai upaya terakhir sebelum upaya litigasi dilakukan. Mediasi sendiri merupakan proses perundingan yang terjadi setidaknya antara 2 (dua) pihak yang mana perundingan tersebut dapat memperoleh kesepakatan karena adanya bantuan mediator sebagai pihak penengah.

Maka, dalam konteks ini, online mediation merupakan proses mediasi yang mana pihak yang bersengketa tidak diwajibkan untuk bertemu secara langsung melainkan secara online. Dengan kata lain, Online mediation atau lebih dikenal dengan e-Mediation merupakan sebuah proses penyelesaian sengketa lintas batas yang dilakukan secara online yang mana mengikutsertakan pihak ketiga (mediator) sebagai pihak penengah. Jadi, para pihak yang bersengketa dapat tetap berada di negara masing-masing atau di negara yang berbeda untuk menyelesaikan sengketa mereka ${ }^{22}$.

Disamping itu, diketahui bahwasanya selain Amerika Serikat, telah terdapat beberapa negara yang telah mengimplementasi metode ODR ini di negara mereka. Adapun negara-negara yang mengimplementasi ODR beserta penjelasan mengenai metode ODR apa saja yang telah diimplementasikan adalah sebagai berikut.

1) European Union (EU) $)^{23}$

Saat ini, European Union (EU) telah mengimplementasikan metode Online Dispute Resolution tepatnya metode e-Resolution guna untuk menyelesaikan sengketa dengan konsumen atas pembelian online namun konsumen tersebut ingin menghindari prosedur pengadilan. Pada proses penyelesaian sengketa tersebut, European Union (EU) membagi tahap penyelesaiannya kedalam 4 (empat) kategori yakni sebagai berikut.

a) Peyampaian keluhan kedalam platform

b) Pada tahap ini, konsumen menyampaikan keluhan dalam Bahasa mereka melalui media platform yang telah disediakan. Kemudian, Penjual tersebut akan menerima daftar badan penyelesaian sengketa yang dapat menangani pengaduan

${ }^{21}$ Amro, I., Sosa, I., Scherer, M., \& Kunz, C. (2020). Online Arbitration in Theory and in Practice: A Comparative Study in Common Law and Civil Law Countries - Kluwer Arbitration Blog. Retrieved 17 December 2020, from http://arbitrationblog.kluwerarbitration.com/2019/04/11/online-arbitration-in-theory-and-in-practice-a-comparative-study-incommon-law-and-civil-lawcountries/\#: :text=In\%20online\%20arbitration\%2C\%20an\%20award,or\%20to\%20a\%20binding\%20arbitration.

${ }^{22}$ Safiullah, M. (2020). Using E-Mediation and Online Mediation Techniques for Conflict. Retrieved 17 December 2020 , from https://www.mediate.com/articles/safiullah-emediation.cfm

23 Online Dispute Resolution: 4 Steps To Better Business. (2021). Retrieved 5 May 2021, from https://europa.eu/youreurope/business/files/odr_infographic_en.pdf 
dalam Bahasa yang Penjual gunakan.

c) Kesepakatan tentang badan penyelesaian sengketa

d) Disini, penjual dan Pembeli akan diberikan waktu selama 30 hari untuk membuat kesepakatan dimana penjual memiliki hak untuk memilih terlebih dahulu. Apabila, penjual tidak setuju atau sepakat, maka, penjual akan kehilangan kesempatan untuk menyelesaikan masalah dengan mudah secara online.

e) Pemerikasaan kasus.

f) Badan penyelesaian perselisihan memiliki waktu 90 hari untuk menemukan solusi.

g) Kasus ditutup.

h) Solusi ditemukan dan penjual beserta Konsumen akan diberi tahu. Pelanggan yang tadinya kecewa sekarang bisa menjadi pelanggan setia sementara penjual dapat mempertahan konsumen mereka.

2) Inggris Raya

HM Online Court (HMOC) adalah ide yang diusulkan di Inggris Raya dimana HMOC merupakan layanan pengadilan baru berbasis Internet dari HM Courts \& Tribunals Service (HMCTS). HMOC kemudian terbagi menjadi layanan dengan tiga tahap ${ }^{24}$.

Pada tahap pertama, HMOC akan membantu pengguna mengevaluasi masalah mereka dan memahami opsi yang tersedia. Tahap pertama akan gratis dan tujuannya adalah untuk mencegah perselisihan meningkat lebih lanjut dengan memberikan informasi hukum yang dapat diandalkan kepada para pihak terkait hak mereka. Pada tahap kedua, fasilitasi online akan dicoba: mediasi dan teknik ADR lainnya akan digunakan untuk mendorong kesepakatan antara para pihak. Jika tidak ditemukan kesepakatan, maka prosedur putusan akan dilakukan pada tahap ketiga oleh anggota Kehakiman (hakim online). Keputusan hakim online akan mengikat dan dapat ditegakkan, seperti keputusan pengadilan tradisional. Tahap kedua dan ketiga dari prosedur HMOC akan memerlukan biaya pengadilan ${ }^{25}$.

3) Afrika Selatan ${ }^{26}$

Afrika Selatan saat ini memiliki dua program ODR yaitu di bidang sengketa nama domain dan sengketa hukum konsumen. ZADRR (ZA Domain Name Dispute Resolution Regulations) dibuat untuk menyelesaikan perselisihan nama domain dengan mengizinkan pengadu untuk mengajukan keluhan kepada penyedia layanan penyelesaian sengketa, yang kemudian menunjuk seorang juri untuk membahas masalah tersebut. Seluruh proses berlangsung secara online dan sejauh ini telah berhasil dalam penyelesaian yang efisien atas perselisihan ini. Di bidang perlindungan konsumen, telah ada pembuatan Onlineombud, yang dibuat sebagai sarana online untuk mengimplementasikan Undang-Undang Perlindungan Konsumen Afrika Selatan. Situs tersebut saat ini adalah satu-satunya situs yang tersedia di mana konsumen dapat menyelesaikan perselisihan mereka secara online dan menggunakan forum online untuk berkontak dengan mediator. Walaupun masih terdapat kesenjangan dalam hal peraturan perundang-undangan ODR di Afrika Selatan, namun program-program tersebut merupakan langkah awal yang baik karena ada peningkatan pengakuan bahwa ODR juga dapat digunakan di wilayah lain hukum Afrika Selatan dan pengakuan ini sejalan dengan cara ODR saat ini diterapkan di beberapa negara Amerika Latin.

4) Australia dan Selandia Baru ${ }^{27}$

Saat ini terdapat keragaman jenis penyelesaian sengketa yang tersedia di negara Australia dan Selandia Baru yakni arbitrase, konsiliasi, keputusan ahli, mediasi dan resolusi perselisihan keluarga. Di Australia dan Selandia Baru saat ini menyediakan sebuah media platform bernama Resolution Institute dimana konsumen dapat memberikan keluhan serta mendapatkan bantuan berupa tenaga ahli yang dapat membantu mereka dalam menyelesaikan perkara

24 Online Dispute Resolution for Low Value Civil Claims. (2015). Retrieved 5 May 2021, from https://www.judiciary.uk/wp-content/uploads/2015/02/Online-Dispute-Resolution-Final-Web-Version1.pdf

${ }^{25}$ Reddy, A., \& Jambulingam, M. (2017). Online Dispute Resolution: A New Approach for E-Commerce Disputes. South East Asia Journal of Contemporary Business, Economic Law, 13(4), 11-17.

26 Cupido, R. V. (2016). The growth of e-commerce and online dispute resolution in developing nations: an analysis. International Journal of Economics and Management Engineering, 10(10), 3371-3374.

${ }^{27}$ Arbitrators make confidential and enforceable decisions for parties - Resolution Institute. (2021). Retrieved 5 May 2021, from https://www.resolution.institute/resolving-disputes/arbitration 
mereka sesuai dengan kebutuhan atau tipe penyelesaian sengketa yang mereka kehendaki sesuai dengan perkara yang mereka hadapi. Pada media platform tersebut juga telah disediakan beberapa informasi dasar agar konsumen dapat memahami jenis layanan penyelesaian sengketa apa yang tepat untuk perkara yang sedang mereka hadapi.

Letak perbedaan penyelesaian sengketa melalui mekanisme ODR ini sendiri sebenarnya tidak jauh berbeda dengan penyelesaian sengketa yang konvensional. Letak perbedaannya hanya terdapat pada metode penyelesaian yang dilakukan melalui internet sebagai penyedia fasilitasnya. Namun, ODR menyediakan beragam manfaat yang tidak tersedia dalam litigasi atau metode penyelesaian sengketa alternatif yang mana sebagai berikut ini.

a. Penghematan biaya.

ODR umumnya merupakan pendekatan yang jauh lebih terjangkau untuk penyelesaian sengketa, terutama jika dibandingkan dengan melalui sistem pengadilan. Pengurangan biaya ini karena fakta bahwa Anda tidak harus menyewa pengacara saat berpartisipasi dalam ODR dan biaya prosedural untuk menggunakan layanan online, dibandingkan dengan biaya perkara, jauh lebih murah.

b. Penghematan waktu.

Sistem pengadilan di Selandia Baru terkenal lambat, karena lamanya waktu yang dibutuhkan untuk menjalani proses aplikasi, kasus pengadilan itu sendiri dan untuk mendapatkan keputusan kembali. Ada juga masalah backlog yang berkembang dalam sistem pengadilan.

Struktur ODR bertujuan untuk mencapai penyelesaian sengketa yang cepat dan efisien. Khususnya untuk pendekatan otomatis untuk penyelesaian sengketa, biasanya untuk menerima solusi atau hasil segera atau tidak lama setelah para pihak menyelesaikan proses.

c. Mudah

ODR juga jauh lebih nyaman daripada litigasi. Karena tidak ada lokasi tetap tempat terjadinya proses resolusi, ODR dapat beroperasi pada waktu dan tempat yang paling nyaman bagi Anda. Fleksibilitas yang meningkat ini juga berarti bahwa Anda tidak perlu mengambil cuti kerja untuk terlibat dalam layanan penyelesaian perselisihan. Demikian pula, Anda tidak harus menyelesaikan seluruh proses penyelesaian dalam satu kesempatan, seperti yang harus Anda lakukan dengan kasus pengadilan.

d. Peningkatan Akses ke Keadilan

Faktor-faktor di atas menunjukkan bahwa ODR memungkinkan banyak orang untuk menggunakan hak dan akses keadilannya. Melalui sifat ODR yang dapat diakses, individu tidak dibatasi untuk menyelesaikan sengketa mereka dengan:

1) status keuangan;

2) letak geografis;

3) kendala waktu; atau

4) disabilitas.

ODR ini muncul karena adanya keterkaitan antara teknologi informasi dan komunikasi dengan mekanisme penyelesaian sengketa alternatif yang banyak digunakan oleh pada pebisnis dan konsumen guna terselesaikannya sengketa yang diakibatkan oleh transaksi perdagangan bisnis. Maka, penyelesaian sengketa dengan menggunakan metode ODR ini merupakan bentuk dari penyelesaian sengketa alternatif yang bersifat eksklusif.

Disamping itu, penerapan yang tepat untuk mengaplikasian metode ODR ini adalah sengketa-sengketa yang memiliki keterkaitan dengan aktivitas perdagangan bisnis internasional terlebih kepada sengketa-sengketa yang bernilai kecil. Jadi ODR ini menyediakan layanan penyelesaian sengketa alternatif dalam bentuk apapun yang mana prosesnya dapat dilakukan melalui internet.

Selanjutnya, ODR sebagai salah satu metode penyelesaian sengketa yang inovatif yang mana salah satu tujuannya yaitu untuk menyelesaikan permasalahan atau sengketa yang disebabkan oleh aktivitas e-Commerce seperti sengketa $e$-Contract. Penyelesaian sengketa dengan menggunakan metode ODR ini tentunya sangat diminati oleh para pelaku kegiatan e-Commerce karena proses pengerjaannya yang cepat, efektif serta efisien.

\section{Prospek Negara Indonesia untuk Menerapkan Online Dispute Resolution}

Di Indonesia sebenarnya telah ada undang-undang yang mengatur mengenai ADR yakni UndangUndang No. 30 Tahun 1999 tentang Arbitrase dan Alternatif Penyelesaian Sengketa atau disingkat dengan UU AAPS. Adapun pengaturan-pengaturan yang dimaksudkan pada undang-undang ini meliputi pengaturan tentang penyelesaian sengketa seputar perbedaan pendapat antara pihak yang bersengketa karena adanya hubungan hukum tertentu maupun karena timbulnya kerugian dikarenakan adanya hukum-hukum tersebut. Jadi, cakupan yang diatur di dalam UU AAPS ini yaitu penilaian ahli, arbitrase, konsultasi, negosiasi, mediasi 
dan konsiliasi termasuk proses beracara dan prosedur yang berlaku pada arbitrase dan/atau upaya alternatif penyelesaian sengketa serta putusan dan pelaksanaan putusannya juga diatur pada UU AAPS inii ${ }^{28}$.

Sementara itu, hubungan antara UU AAPS dengan ODR, walaupun ODR dapat diimplementasikan, namun belum ada keterkaitan yang mencakup pengaturan mengenai ODR. Maka dari itu, akibat dari timbulnya perselihan yang pada umumnya timbul karena adanya perjanjian, para pelaku bisnis yang berperkara dapat dengan bebas dalam menentukan forum dalam perjanjian tersebut termasuk penggunaan ADR maupun ODR. Meski demikian, prosedur beracaranya tetap mengaplikasikan UU AAPS serta peraturan lemabaga arbitrase dan alternatif penyelesaian sengketa.

Disamping itu, UU No.11 Tahun 2008 tentang Informasi dan Transaksi Elektronik yang kemudian diubah dengan UU No. 19 Tahun 2016 tentang Informasi dan Transaksi Elektronik serta Peraturan Pemerintah No. 80 Tahun 2019 tentang Perdagangan Sistem Elektronik atau disingkat dengan PP juga dapat digunakan sebagai dasar pengaplikasian ODR spesifiknya untuk permasalahan e-Commerce. Sebagaimana disebutkan pada Peraturan Pemerintah, penyelesaian sengketa e-Commerce dapat dilakukan secara online dengan menggunakan ODR sesuai dengan ketentuan peraturan perundang-undangan ${ }^{29}$.

Maksud dari ODR pada Peraturan Pemerintah e-Commerce yaitu Lembaga yang terakreditasi atau Lembaga pemerintahan yang berwenang yang menyelenggarakan ODR harus didukung oleh pendukung yang profesional seperti mediator atau advokat. Adapun pemilihan forum ODR itu ditentukan berdasarkan kesepakatan antara pihak yang melakukan transaksi atau perdagangan bisnis secara online termasuk pilihan forum serta hukum dalam penyelesaian sengketa lintas batas. Namun, asas Hukum Perdata Internasional berlaku apabila para pihak tidak menentukan forum serta hukum sekiranya terjadi sengketa ${ }^{30}$.

Jadi, dengan hadirnya regulasi ADR dan e-Commerce di Indonesia telah menunjukkan bahwa setidaknya ODR telah mempunyai dasar regulasi yang dapat mendukung pelaksanaannya. Meskipun belum ada pengaturan yang spesifik sehubungan ODR, aturan-aturan yang sebagaimana telah dijabarkan diatas telah dapat menjadi patokan dalam membuat peraturan-peraturan mengenai ODR secara lebih mendetail. Hal ini dikarenakan pentingnya peraturan-peraturan yang secara khusus mengatur tentang ODR agar ODR dapat menjadi pilihan bagi para pelaku praktik perdagangan bisnis khususnya pada penyelesaian sengketa antara para pihak yang bersengketa.

3. Manfaat Serta Tantangan Yang Akan Di Hadapi Indonesia Apabila Penyelesaian Sengketa Online Benar Di Berlakukan Di Indonesia.

Merujuk Kemudian, terdapat manfaat-manfaat dalam pengaplikasian ODR apabila penerapan ODR diberlakukan di Indonesia, yang mana diantaranya adalah sebagai berikut ini.

a. $\quad$ Pengkematan waktu serta biaya

Tidak dapat dipungkiri bahwa apibila penyelesaian sengketa dapat dilakukan secara online pastinya ini akan sangat membantu para pelaku bisnis yang berperkara dalam penghematan biaya dan waktu akibat dari timbulnya sengketa karena aktifitas perdagangan listas batas. Dengan adanya prosedur yang dapat dilakukan secara online, prosedur yang dimana mengharuskan para pihak yang berlokasi di ngeara berbeda untuk bertemu secara langsung dapat mempercepat proses dan prosedur penyelesaian sengketa mereka karena mereka dapat melakukannya secara virtual.

b. Kenyamanan Prosedur ODR

ODR sendiri menyediakan pelayanan berbentuk komunikasi dengan menggunakan sistem asynchronous. Asynchronous.merupakan sistem TIK yang dapat menunjang penyelesaian sengketa via ODR dngan memanfaatkan porgram yang terkendali untuk pengguna tanpa harus menunggu prosse dan tidak memakan waktu yang lama. Dengan adanya sistem komunikasi ini, para pihak berperkara dapat saling bertukar pikiran serta pendapat mereka tanpa harus merasa terintimidasi lawan pihak. Karena pada umumnya pihak yang dituntut memiliki rasa takut serta terintimidasi oleh oihak lawan. Jadi masalah psikologis seperti ini dapat teratasi.

c. Pemilihan pihak ketiga

Pada poin ini para pihak dapat memiliki control yang lebih atas perkara yang mereka hadapi karena mereka dapat memilih pihak ketiga yang dalam konteks ini disebut sebagai arbiter guna untuk menyelesaikan sengketa yang mereka hadapi.

Alasan ini didasari oleh kurangnya efektivitas dalam penyelesaian sengketa yang mana sering ditemukannya ketidak kooperatifan dari pengadilan yang disebabkan karena adanya pertentangan antara

\footnotetext{
${ }^{28}$ Faiz Aziz, M., \& Arif Hidayah, M. (2020). Loc.Cit

${ }^{29}$ Sugiarto, S. (2019). Loc. Cit.

${ }^{30}$ Gerarita Sitompul, M., Syaifuddin, M., \& Yahanan, A. (2016). Loc. Cit.
} 
teritorialitas pengadilan. Sehingga dengan adanya ODR diharapkan penyelesaian sengketa dapay diselesaikan dengan cara yang lebih efektif.

Disamping kebebasan dalam memilih metode penyelesaian sengketa, juga terdapat prinsip kebebasan dalam memiliki forum hukum yang mana pada perinsip ini pengadilan akan memberikan putusan berdasarkan prinsip keadilan, kepatutan atau kelayakan terhadap kasus sengketa yang disengketakan.

Sementara itu terdapat kendala dan tantangan yang dapat menghambat penerapan ODR di Indonesia yang mana poin-poin tersebut akan dijelaskan sebagai berikut ini.

a. Hambatan teknologi, akses dan keterjangkauan.

Tentunya ini merupakan kendala paling utama yang pastinya menjadi hambatan dalam proses pengimplementasian ODR di Indonesia, Karena Indonesia merupakan sebuah negara yang tediri dari ribuan pulau yang tersebar luas dan terpisah. Sehingga akses dan keterjangkauan terknologi dan internet belum sevara merata tersebar sekeluruh pelosok tanah air.

b. $\quad$ Kendala terhadap keamanan sistem dan kerahasiaan data pribadi.

Karena sistem pelayanan dan proses pelaksanaan ODR dilakukan secara online, tentunya semua proses penyelesaian sengketa tersebut di rekam dan disimpan dalam bentuk elektronik. Ini dapat menjadi kendala dikarenakan adanya isu mengenai ancaman kerahasiaan dan keamanan terhadap data pribadi yanga mana data tersebut dapat diretas oleh oknum-oknum tidak bertanggung jawab sehingha ini dapat berdampak kepada tingkat keamanan teknologi ODR terhadap data pribadi milik para pihak bersengketa.

\section{SIMPULAN}

Saat ini, semua transaksi maupun perdagangan bisnis mulai mengarah kepada electronic commerce atau disingkat sebagai e-commerce. E-commerce sendiri merupakan sebuah bisnis model yang mengizinkan perusahaanperusahaan maupun individu untuk melakukan transaksi perdagangan bisnis melalui internet atau secara online. Namun, dengan adanya kegiatan transaksi perdagangan e-commerce, membuat para pelaku transaksi bisnis dapat menjangkau klien mereka dengan menawarkan ragam varian produk serta pelayanan yang tidak terbatas sehingga ecommerce dianggap sebagai suatu inovasi yang disruptif. Alasan mengapa e-commerce disebut sebagai suatu inovasi yang disruptif adalah dengan adanya inovasi baru seperti e-commerce telah membuat sebuah pasar dan juga layanan networking baru yang tentunya mengganggu pasar dan layanan networking yang sudah ada. Sehingga inovasi ecommerce ini telah menimbukan ragam sengketa yang baru yang mana kemudian disebut sebagai e-commerce dispute. Karena semakin meningkatnya kegiatan e-commerce ini makan peluan akan munculnya suatu sengketa yang disebabkan oleh e-commerce akan semakin besar. Untuk itu, diperlukan pula suatu sistem yang sederhana namun tepat, cepat dan tentunya efektif serta efisien guna untuk mengatasi adanya permasalahan yang disebabkan oleh kegiatan transaksi perdangangan bisnis menggunakan e-commerce.

Dengan demikian, Alternative Dispute Resolusion merupakan solusi untuk menyelesaikan sengketa secara online dan non-litigasi. Melalui jalur ODR pihak yang bersengketa dapat tetap berada di negara masing-masing tanpa harus bertemu secara langsung untuk menyelesaikan sengketa mereka. Pada saat ini terdapat 4 macam sistem penyelesaian sengketa yang menggunakan mekanisme ODR yaitu Online Settlement, Online Arbitration, online resolution dan online mediation. Namun ada beberapa yang harus di perhatikan apabila Indonesia ingin mengimplementasikan metode ODR ini yaitu Indonesia perlu untuk memperhatikan dan mempertimbangkan perihal hambatan teknologi, akses dan keterjangkauan serta kendala terhadap keamanan sistem dan kerahasiaan data pribadi. Karena, dua poin ini akan sangat berpengaruh kepada keamanan dan kenyamanan pengguna yang memiliki kemampuan serta jangkauan untuk memanfaatkan fasilitas ODR tersebut jika suatu saat nanti metode ODR ini diimplementasikan di Indonesia. 


\section{DAFTAR PUSTAKA}

\section{BUKU}

Kaufmann-Kohler, G., \& Schultz, T. (2004). Online dispute resolution (pp. 5-9). The Hague: Kluwer law international.

\section{JURNAL}

Aziz, M., \& Hidayah, M. (2020). Perlunya Pengaturan Khusus Online Dispute Resolution (ODR) Di Indonesia Untuk Fasilitasi Penyelesaian Sengketa E-Commerce. Jurnal Rechts Vinding: Media Pembinaan Hukum Nasional, 9(2), 275-278. doi: 10.33331/rechtsvinding.v9i2.449

Chandra, A. (2014). Penyelesaian Sengketa Transaksi Elektronik Melalui Online Dispute Resolution (ODR) Kaitan dengan UU Informasi dan Transaksi Elektronik No. 11 Tahun 2008. Jurnal Ilmu Komputer, 10(2).

Cupido, R. V. (2016). The growth of e-commerce and online dispute resolution in developing nations: an analysis. International Journal of Economics and Management Engineering, 10(10), 3371-3374.

Faiz Aziz, M., \& Arif Hidayah, M. (2020). Perlunya Pengaturan Khusus Online Dispute Resolution (ODR) Di Indonesia Untuk Fasilitasi Penyelesaian Sengketa E-Commerce. Jakarta Selatan: Sekolah Tinggi Hukum Indonesia Jentera.

Gerarita Sitompul, M., Syaifuddin, M., \& Yahanan, A. (2016). Online Dispute Resolution (Odr): Prospek Penyelesaian Sengketa E-Commerce Di Indonesia. Palembang. Retrieved from https://media.neliti.com/media/publications/255784-online-dispute-resolution-odr-prospek-pe-52db2b41.pdf

Iswandari, D. (2018). Teori Perdagangan Internasional. Retrieved 14 December 2020, from http://eprints.ums.ac.id/59653/7/BAB\%20II.pdf

Lam, W., 2018. Metode Penelitian. [online] Repository.uib.ac.id. Available at: <http://repository.uib.ac.id/1146/6/S_1451010_chapter3.pdf> [Accessed 19 December 2020].

Lumbanraja, A. D. (2020). Perkembangan Regulasi Dan Pelaksanaan Persidangan Online Di Indonesia Dan Amerika Serikat Selama Pandemi Covid-19. CREPIDO, 2(1), 46-58. https://doi.org/10.14710/crepido.2.1.46-58

Reddy, A., \& Jambulingam, M. (2017). Online Dispute Resolution: A New Approach for E-Commerce Disputes. South East Asia Journal of Contemporary Business, Economic Law, 13(4), 11-17.

Sitompul, M. G., Syaifuddin, M., \& Yahanan, A. (2016). Online Dispute Resolution (ODR): Prospek Penyelesaian Sengketa E-Commerce di Indonesia. Jurnal Renaissance, 1(2), 75-93.

Sugiarto, S. (2019). Online Dispute Resolution (Odr) Sebagai Alternatif Penyelesaian Sengketa Di Era Modernisasi

Sutiyoso, B. (2008). Penyelesaian Sengketa Bisnis Melalui Online Dispute Resolution dan Pemberlakuannya di Indonesia. Mimbar Hukum-Fakultas Hukum Universitas Gadjah Mada, 20(2), 229-250.

Tsurel, D., Doron, M., Nus, A., Dagan, A., Guy, I., \& Shahaf, D. (2020). E-Commerce Dispute Resolution Prediction (pp. 1465-1474). Virtual Event, Ireland: Association for Computing Machinery.

Van Den Heuvel, E. (2020). Online Dispute Resolution As A Solution To Cross-Border E-Disputes. Retrieved 17 December 2020, from http://www.oecd.org/digital/consumer/1878940.pdf

\section{SUMBER INTERNET (MEDIA ONLINE)}

Amro, I., Sosa, I., Scherer, M., \& Kunz, C. (2020). Online Arbitration in Theory and in Practice: A Comparative Study in Common Law and Civil Law Countries - Kluwer Arbitration Blog. Retrieved 17 December 2020, from http://arbitrationblog.kluwerarbitration.com/2019/04/11/online-arbitration-in-theory-and-in-practice-acomparative-study-in-common-law-and-civil-lawcountries/\#: :text=In\%20online\%20arbitration\%2C\%20an\%20award,or\%20to\%20a\%20binding\%20arbitration.

Elena, M. (2020). Transaksi E-Commerce Meningkat 79,38 Persen di Tengah Resesi Ekonomi | Ekonomi Bisnis.com. Retrieved 5 May 2021, from https://ekonomi.bisnis.com/read/20201109/9/1315333/transaksi-ecommerce-meningkat-7938-persen-di-tengah-resesi-ekonomi

Arbitrators make confidential and enforceable decisions for parties - Resolution Institute. (2021). Retrieved 5 May 2021, from https://www.resolution.institute/resolving-disputes/arbitration

$\begin{array}{llllll}\text { Metode } & \text { Penelitian. } & \text { (2020). } & \text { Retrieved } & \text { from }\end{array}$ http://repository.uib.ac.id/1151/6/S_1451007_chapter3.pdf

Online Dispute Resolution for Low Value Civil Claims. (2015). Retrieved 5 May 2021, from https://www.judiciary.uk/wp-content/uploads/2015/02/Online-Dispute-Resolution-Final-Web-Version1.pdf

Online Dispute Resolution: 4 Steps To Better Business. (2021). Retrieved 5 May 2021, from https://europa.eu/youreurope/business/files/odr_infographic_en.pdf

Safiullah, M. (2020). Using E-Mediation and Online Mediation Techniques for Conflict. Retrieved 17 December 2020, from https://www.mediate.com/articles/safiullah-emediation.cfm 
UNCITRAL Technical Notes on Online Dispute Resolution. (2017). Retrieved 9 March 2021, from https://uncitral.un.org/sites/uncitral.un.org/files/media-

documents/uncitral/en/v1700382_english_technical_notes_on_odr.pdf

\section{PERATURAN PERUNDANG-UNDANGAN}

Republik Indonesia, Undang-Undang Dasar 1945

Kitab Undang-Undang Hukum Perdata

Undang-Undang No. 30 Tahun 1999 tentang Arbitrase dan Alternatif Penyelesaian Sengketa

Undang-Undang No. 19 Tahun 2016 tentang Informasi dan Transaksi Elektronik

Peraturan Pemerintah No. 80 Tahun 2019 tentang Perdagangan Sistem Elektronik 